\title{
Value creation in family firms: A model of fit
}

\author{
Nadine Kammerlander ${ }^{\mathrm{a}, *}$, Philipp Sieger ${ }^{\mathrm{a}}$, Wim Voordeckers ${ }^{\mathrm{b}}$, Thomas Zellweger ${ }^{\mathrm{a}}$ \\ ${ }^{a}$ University of St. Gallen, Dufourstrasse 40a, CH-9000 St. Gallen, Switzerland \\ ${ }^{\mathrm{b}}$ University of Hasselt, Martelarenlaan 42, B-3500 Hasselt, Belgium
}

\section{A R T I C L E I N F O}

\section{Keywords:}

Family firm

Value creation

Governance

Contingency view

Goals

Resources

\begin{abstract}
A B S T R A C T
We propose a framework describing how family ownership can create or destroy value depending on the goals, resources, and governance of the family firm, which are each influenced by the family owners. Taking a contingency perspective, we suggest that a fit is required for all three elements - familyinfluenced goals, resources, and governance - for the family firm to flourish over generations. We conclude with a suggested research agenda indicating research opportunities at the nexus of these identified elements. Further we provide some guiding questions for practitioners that might stimulate fruitful discussions among family firm owners and managers about how to realize "fit."
\end{abstract}

() 2015 Published by Elsevier Ltd.

\section{Introduction}

How does family ownership either create or destroy value? This is clearly one of the core questions that researchers and practitioners alike have tried to answer throughout recent decades. While several studies have argued that competitive advantages, such as patient capital and social capital, accompany family ownership (Miller \& Le Breton-Miller, 2005; Pearson, Carr, \& Shaw, 2008) and ultimately lead to superior financial performance (e.g., Anderson \& Reeb, 2003), others have emphasized the idiosyncratic disadvantages of family firms (Cabrera-Suarez, Saa-Perez, \& Garcia-Almeida, 2001; Lee \& Rogoff, 1996), such as conflicts among family members and resource scarcity, which deteriorate firm performance (cf. Morck \& Yeung, 2003). Despite the abundance of theoretical arguments and empirical evidence for family firms' competitive advantages and disadvantages, a comprehensive perspective of value creation in family firms is still lacking.

In this editorial, we aim to advance the current debates on value creation in family firms by taking a contingency view (Drazin \& Van de Ven, 1985) and by proposing a model of fit that aims to contribute to integrating prior research and explaining value creation (or destruction) in family firms. We thereby take a broad perspective on value creation, not only focusing on the financial

\footnotetext{
* Corresponding author. Tel.: +41712247116.

E-mail addresses: nadine.kammerlander@unisg.ch (N. Kammerlander), philipp.sieger@unisg.ch (P. Sieger),wim.voordeckers@uhasselt.be (W. Voordeckers), thomas.zellweger@unisg.ch (T. Zellweger).
}

success of the family firm but also taking the overall utility function of family owners into account; this utility is based on both financial and non-financial aspects. In the following, we first present a model of fit and explain how the five articles published in this special issue contribute to advancing this model and to explaining value creation in family firms. In a second step, we further elucidate the nexus of the individual elements of the value creation model. In a last step, we note promising avenues for further research and highlight questions that family owners and managers might ask to identify a "fit" within their firm and to create value.

The intention of this editorial piece is to stimulate further discussion among scholars, family firm owners, and advisors about the modes how family firms can create value over time. We also aim to raise awareness about the contingency effects of value creation in family firms, thereby emphasizing the critical need to have an integrated perspective on family firms instead of only illuminating selected items and drawing overhasty conclusions based on a narrow set of information.

\section{Value creation in family firms-A model of fit}

The core "ingredients" of value creation in family firms

A multitude of different perspectives have been used in prior research to explain why family firms out- or underperform other businesses and thereby create or destroy value. In general, those studies can be classified into three categories.

One cluster of research (arrow 1 in Fig. 1) has examined the idiosyncratic goals in family firms, how they are influenced by 


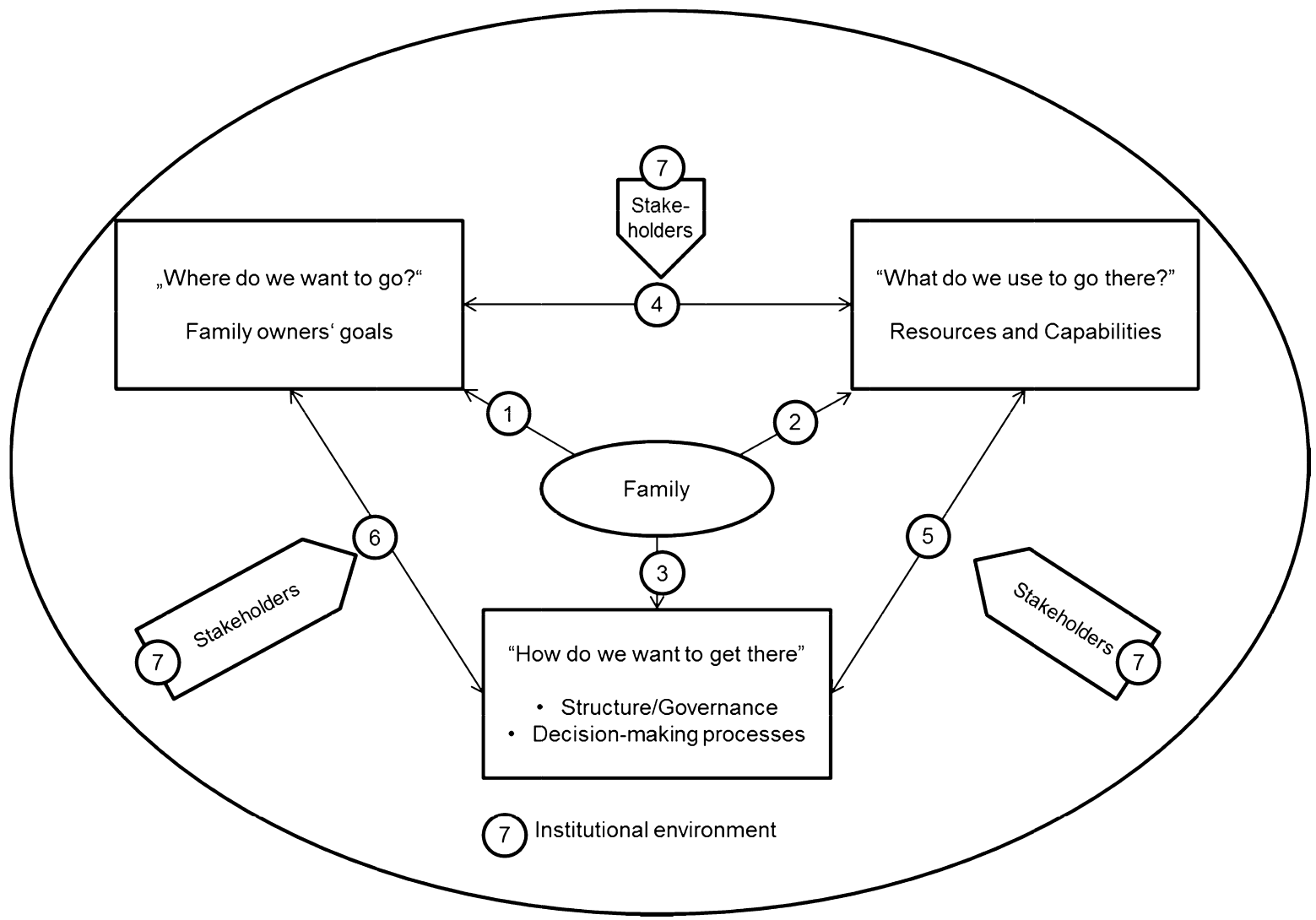

Fig. 1. Model of value creation in family firms.

family owners, and how they, ultimately, affect organizational behavior and value creation. Indeed, the fact that family owners influence their business by infusing their family goals and priorities has been long claimed in family business literature (Tagiuri \& Davis, 1996). For instance, research on socio-emotional wealth (Berrone, Cruz, \& Gómez-Mejía, 2012; Gómez-Mejía, Takács Haynes, Núnez-Nickel, Jacobson, \& Moyano-Fuentes, 2007), building upon the behavioral agency model (Wiseman \& Gómez-Mejía, 1998), has indicated the various socio-emotional endowments of family owners, which lead them to follow specific, non-financial goals such as maintaining control over the firm (Zellweger, Kellermanns, Chrisman, \& Chua, 2012) or investing in long-lasting, trust-based bonds. This focus on non-financial goals, in turn, has been shown to affect family firm behavior such as environmental performance (Berrone, Cruz, Gómez-Mejía, \& Larraza-Kintana, 2010) or adaptation to technological innovations (Kammerlander \& Ganter, 2015).

A second stream (arrow 2 in Fig. 1), mostly building on the resource based view (Barney, 1991), has emphasized the role of the resources and capabilities that allow family firms to create value. For instance, researchers have noted the competitive advantages created through "familiness," denoting the "bundle of resources that are distinctive to a firm as a result of family involvement" (Habbershon \& Williams, 1999: 1). Examples of such beneficial resources in family firms are family-specific social capital (Pearson et al., 2008), human capital (cf. Sharma, 2008), or reputational capital (Sieger, Zellweger, Nason, \& Clinton, 2011). Yet turning the focus from value creation to value destruction, a family firmspecific lack of resources, such as a scarcity of financial resources for investment in radical new technologies (König, Kammerlander, \& Enders, 2013), might also destroy rather than create value.

Lastly, value creation in family firms is a function of the governance structures within and around those organizations (arrow 3 in Fig. 1). For instance, family owners likely affect organizational structures (Corbetta \& Salvato, 2004) and executive compensation (Gómez-Mejía, Larraza-Kintana, \& Makri, 2003), which in turn have been found to affect the efficient functioning of the organization. More specifically, the family firm's monitoring systems and incentive schemes determine the managers' leeway and motivation for pursuing activities in their own instead of the owners' interest (Chrisman, Chua, \& Litz, 2004) and these structures also determine the efficiency of information processes within the firm as well as the family firm's speed of adaptation. While governance structures are determinants of value creation in any firm, family owners affect the governance structures of their firms in particular ways. For instance, family firms have been found to have idiosyncratic contracts and compensation mechanisms (Block, 2011), fewer hierarchical levels (Boyd, 2010), and in general, a different set of agency problems (Schulze, Lubatkin, \& Dino, 2003; Schulze, Lubatkin, Dino, \& Buchholtz, 2001).

How the articles of this issue advance knowledge on value creation in family firms

The next section will elaborate on the five articles published in this special issue and will outline how they contribute to understanding value creation in family firms. One article (Hauck \& Prügl, 2015) addresses the goals of family firms (arrow 1 in Fig. 1), one article (Ahrens, Landmann, \& Woywode, 2015) studies the resources within family firms (arrow 2 in Fig. 1), and three articles (Engel, Hack, \& Kellermanns, 2015; Lopez-Delgado \& Dieguez-Soto, 2015; Sitthipongpanich \& Polsiri, 2015) focus on governance in family firms (arrow 3 in Fig. 1). Table 1 provides an overview of the five articles, their theoretical backbones, empirical approaches, and core findings. 
Table 1

Overview of papers in the special issue.

\begin{tabular}{|c|c|c|c|c|}
\hline Authors & $\begin{array}{l}\text { Arrow } \\
\text { in Fig. } 1\end{array}$ & Theoretical basis & Empirics & Main findings \\
\hline Hauck \& Prügl & 1 & Socio-emotional wealth & $\begin{array}{l}\text { Survey data of } 81 \text { family } \\
\text { owner-managers (incumbents) } \\
\text { of Austrian family firms in the } \\
\text { tourism sector }\end{array}$ & $\begin{array}{l}\text { Family firm owner-managers differ in their willingness } \\
\text { to see an upcoming succession as opportunity for } \\
\text { innovation and change } \\
\text { Variance in perception is driven by socioemotional } \\
\text { aspects } \\
\text { Family adaptability and closeness to the family firm } \\
\text { foster innovation, while a history of family bonds and } \\
\text { intergenerational authority impede innovation }\end{array}$ \\
\hline $\begin{array}{l}\text { Ahrens, Landmann, \& } \\
\text { Woywode }\end{array}$ & 2 & $\begin{array}{l}\text { Contest theory; human } \\
\text { capital }\end{array}$ & $\begin{array}{l}\text { Archival and survey data on } \\
804 \text { successions in German } \\
\text { family firms taking place } \\
\text { between } 2002 \text { and } 2008\end{array}$ & $\begin{array}{l}\text { Incumbents prefer male over female successors } \\
\text { Female family successors have higher levels of human } \\
\text { capital than male family successors } \\
\text { The presence of sons is positively correlated to } \\
\text { succession contests based on nepotism }\end{array}$ \\
\hline $\begin{array}{l}\text { Lopez-Delgado \& } \\
\text { Dieguez-Soto }\end{array}$ & 3 & $\begin{array}{l}\text { Literature on governance, } \\
\text { family influence, and } \\
\text { performance }\end{array}$ & $\begin{array}{l}\text { Archival data (System of } \\
\text { Spanish Balance Sheets-SABI- } \\
\text { database) } \\
3890 \text { private firms }\end{array}$ & $\begin{array}{l}\text { Lone-founder firms perform better than family } \\
\text { businesses } \\
\text { Direct effect of family ownership on private firm } \\
\text { performance is not confirmed }\end{array}$ \\
\hline $\begin{array}{l}\text { Sitthipongpanich \& } \\
\quad \text { Polsiri }\end{array}$ & 3 & $\begin{array}{l}\text { Governance literature, } \\
\text { agency theory }\end{array}$ & $\begin{array}{l}\text { Archival data (firms listed on } \\
\text { the Stock Exchange of Thailand) } \\
832 \text { firm-year observations }\end{array}$ & $\begin{array}{l}\text { Having a family CEO may reduce firm value } \\
\text { Firm value is contingent on family CEO characteristics } \\
\text { as well as on board characteristics }\end{array}$ \\
\hline $\begin{array}{l}\text { Engel, Hack \& } \\
\text { Kellermanns }\end{array}$ & 3 & $\begin{array}{l}\text { Agency theory; } \\
\text { socioemotio-nal wealth }\end{array}$ & $\begin{array}{l}\text { Archival data on } 203 \text { German } \\
\text { publicly listed firms (datasets } \\
\text { provided by consultants, } \\
\text { complemented by data from } \\
\text { Bureau van Dijk) }\end{array}$ & $\begin{array}{l}\text { Non-family and family firms do not differ with regard to } \\
\text { performance-related pay adoption } \\
\text { When performance-related pay is adopted, true family } \\
\text { firms grant higher shares of performance-related pay }\end{array}$ \\
\hline
\end{tabular}

Hauck and Prügl (2015) study the importance of family goals and priorities for the proclivity towards innovation in family firms. Their results show that socioemotional factors (Berrone et al., 2012) have both a dark and a bright side and thus can contribute to value creation or value destruction within the family firm. More specifically, Hauck and Prügl use survey responses from ownermanagers of Austrian family firms in the tourism sector that are close to succession. They reveal that the willingness of incumbents to see the upcoming succession phase as opportunity for innovation and change crucially depends on the family's priorities: While family adaptability and closeness to the firm are associated with an increased willingness to support innovation, intergenerational authority and a history of family bonds are negatively related to the innovation proclivity.

Ahrens et al. (2015) empirically study the human capital of 804 successors. They find that family-internal female successors are chosen less frequently than their male counterparts but are equipped, on average, with higher human capital. It is due to nepotism in succession contests, these authors argue based on contest theory (Konrad, 2009), that if a son is chosen as successor, the level of human capital is lower compared to non-family successors. Their findings might not only pave the way to an increased understanding of the role of women in family businesses (Cole, 1997; Hollander \& Bukowitz, 1990) but might also explain the underperformance of family-internal compared to familyexternal successors (Wennberg, Wiklund, Hellerstedt, \& Nordqvist, 2011). They thus contribute to an improved understanding of how family influence can entail a lack of resources, which has potential detrimental consequences for value creation in those firms.

Lopez-Delgado and Dieguez-Soto (2015) investigate the effects of family on the performance of non-listed firms. More specifically, these authors examine whether lone-founder or family firms perform differently. The analysis of a sample of 3890 privately held Spanish firms shows, for instance, that lone-founder firms perform better than family businesses in a private firm context. While, on a general level, a direct effect between the degree of family ownership and private firm performance could not be confirmed, their detailed analysis reveals important insights into the effect of governance on value creation. More specifically, when family businesses are characterized by ownership concentration in the hands of family and, simultaneously, non-family management, their performance is found to be significantly lower than that of other types of firms. Overall, the findings presented by this study largely confirm existing findings generated in the public firm context (e.g., Anderson \& Reeb, 2003; Miller, Le Breton-Miller, Lester, \& Cannella, 2007), particularly by showing that founder-led firms may exhibit stronger financial performance (He, 2008), and extend them by providing nuanced insights into which aspects drive value creation.

The paper of Sitthipongpanich and Polsiri (2015) in this special issue studies how CEO and board characteristics are related to firm value in Thai family firms. The results show that having a family CEO may reduce firm value. However, this effect is contingent on the family CEO's age, business expertise, and social network. Interestingly, the value of firms with a family CEO is enhanced when the board of directors is composed of members of diverse ages and with strong political ties. Taken together, this study sheds a nuanced light on how family CEO characteristics and board characteristics interact in determining family firms' value, notably in a context with weak institutions (Peng \& Jiang, 2010). This enhances the general literature addressing how family involvement and governance aspects affect value creation (Bertrand, Johnson, Samphantharak, \& Schoar, 2008; Luo \& Chung, 2013).

Finally, the study of Engel et al. (2015) in this special issue combines agency theory and the socioemotional wealth (SEW) literature to investigate the determinants of outside directors' pay mix and the family's influence on that decision in public family firms. Contrary to initial expectations, family and non-family firms do not significantly differ concerning the likelihood of adopting performance-related pay. This might be explained by the fact that in publicly listed family firms, two main forces appear to be at work. First, SEW-based reluctance to implement performancerelated pay and second, conformity pressures (Miller, Le BretonMiller, \& Lester, 2013) to adopt performance-related pay to satisfy non-family shareholders' demands. Among those firms that do adopt performance-related pay, "true family firms" in particular that is, family firms in which multiple family members are involved as either top managers or significant shareholders - grant 
higher shares of performance-related pay than other types of firms. As a whole, these findings enrich the body of research on family firms and compensation patterns.

\section{A model of fit}

While much research effort has been dedicated to studying how family ownership affects goals, resources, and governance in the respective firms (e.g., Carney, 2005; Chrisman, Chua, Pearson, \& Barnett, 2012; Habbershon, Williams, \& MacMillan, 2003; Sirmon \& Hitt, 2003) and, ultimately, firm performance (O'Boyle, Pollack, \& Rutherford, 2012; Wagner, Block, Miller, Schwens, \& Xi, 2015), the extant scholarly view on family firm value creation still remains fragmented. In particular, most prior research has focused on a single aspect of the family firm value creation model - e.g., either goals, resources, or governance - and studied its implications for firm performance. Contingency based theory (Drazin \& Van de Ven, 1985), however, encourages scholars to avoid looking at singular effects and to consider the important effects of "fit" among the various aspects instead, as well as the fit of the specific firm with its environmental surroundings. This call for an integrated view that takes multiple levels - the environment, the owners, and the organization - into account is also in line with the "strategy as practice" paradigm (Jarzabkowski, 2004; Whittington, 1996), which propagates a closer integration of different institutional and organizational levels, a more in-depth consideration of who the actors actually are, and the contemplation of reinforcing mechanisms.

Applied to the presented model of family firm value creation (see Fig. 1), this perspective means that scholars and practitioners need to take the fit of the family firms' goals, resources, and governance into account to be truly able to draw conclusions about value creation within those firms. In other words, even when a family firm has managed to build up unique resources, if these resources do not match the requirements of the firm's context, value creation is unlikely. As another example, the deployment of even the most useful and valuable resources is inefficient if governance structures are set up in a way that impedes purposeful resource orchestration. When there is a misfit between the familyspecific goals in the family firm and the output created by the firm's specific resources within the given governance structures, the created "value" will likely not be perceived as being "valuable" by the family owners. Creating fit among several "ingredients of value creation" - in our framework, goals, resources, and governance - raises the question of which of the three elements - goals, resources, or structure - should be prioritized when initializing the "fitting process."

\section{Prioritizing strategic goals: Opportunities and challenges}

Some family firms may decide to prioritize goals in their strategizing. This approach holds the promise of aligning the goals of the family principals with strategic actions at the firm level. Advocates of such a goal-centered approach implicitly assume that the goal setters, in most cases the family principals who sit at the apex of the corporate pyramid, have sufficient information about the opportunities and threats related to the pursuit of these goals and about the attainability of the goals. Indeed, the pursuit of strategic goals as an outflow of a planning process pays off for more established companies operating in rather stable environments (Brinckmann, Grichnik, \& Kapsa, 2010). Such a causation focus, however, comes at the risk of neglecting the available resources and prevailing governance structures. In this case, strategizing may remain a sandtable exercise. For instance, high-flying goals of family owners may be decoupled from the mobilizable resources and prevailing governance structures such as incentives and control structures. In the extreme case, goal-centered approaches to strategizing may end in frustration of the family (about the inability to achieve the goals) and the firm (about the unrealistic goals at the outset).

With respect to the content and importance of family owners' goals, we can distinguish between three archetypical categories of family firms (see Fig. 2). We term the first category "dreamers," and hence these represent firms that focus solely on non-financial goals with less attention to financial goals. The issue with this category is that the long-term sustainability of such an organization is at stake due to the lack of focus on financial achievements. For instance, to uphold a positive image and maintain effectiveness, this type of family-managed firm may go deep into negative financial results and miss upcoming opportunities before rejuvenating their business model (Kellermanns, Eddleston, \& Zellweger, 2012). This type of family firm might suffer from severe competitive disadvantages compared to other firms in the industry and might thus eventually disappear from the competitive arena.

In contrast, we term the second category as "traders." These represent family owners with a focus on financial goals alone. These firms forgo important opportunities tied to family involvement, such as employee loyalty (Miller \& Le Breton-Miller, 2005) or brand reputation (Krappe, Goutas, \& von Schlippe, 2011), just as they forgo efficiency in innovation processes (Duran, Kammerlander, van Essen, \& Zellweger, 2015). Such firms may thus fall prey to the pitfalls of short-termism and managerial myopia.

The third category, "professional owners," denotes those family owners that pursue both financial and non-financial interests simultaneously. While financial and non-financial goals are often contradictory, theory on paradoxes (Lüscher \& Lewis, 2008; Smith \& Lewis, 2011) provides guidelines for how to handle this ongoing struggle between priorities and how to leverage synergies to the best possible degree. This view emphasizes that pursuing solely financial or nonfinancial goals is destructive because it promotes entropy and unproductive schismogenesis, defined as a "process of self-reinforcement where one action or attribute in the organization perpetuates itself until it becomes extreme and therefore dysfunctional" (Cameron, 1986: 546). Similar to research on organizational ambidexterity (Andriopoulos \& Lewis, 2009; Gibson \& Birkinshaw, 2004; Kammerlander, Burger, Fust, \& Fueglistaller, 2014), which states that successful firms need to pursue both exploratory and exploitative activities, we propose that family firms and what we label professional family business owners need also to become ambidextrous with regard to their goals. The underlying idea behind ambidextrous goal setting is that resolving all simultaneous contradictions and pursuing logical consistency may, in fact, inhibit excellence by eliminating the creative tension produced by paradoxes (Locke \& Latham, 2002; Zellweger, 2013).

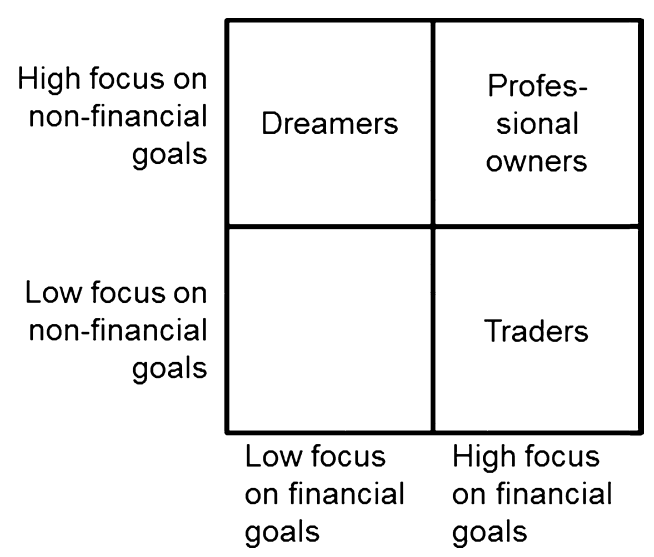

Fig. 2. Categories of family owners based on goals. 
In the end, a balanced pursuit of financial as well as non-financial goals should help family owners to maximize their utility function.

\section{Prioritizing available resources: Opportunities and challenges}

Alternatively, some family firms may prioritize available resources and start their "fitting process" accordingly. Such firms pursue what entrepreneurship scholars have labeled an effectuation-based approach (Sarasvathy, 2001). This effectuational approach to strategizing is implicitly advocated in the familiness literature (Habbershon \& Williams, 1999), which calls for a generic assessment of productive and restraining familiness, in disconnect from the eventual strategic goals of the firm. This view neglects and even calls into question the usefulness of ex ante strategic goals. While this approach is effective, in particular in times of uncertainty and in particular upon firm foundation, it brings the danger of becoming a "reactor" instead of an "actor." Rather than using their superior power and ability (Chrisman et al., 2014), family firms that focus too much on available resources and too little on strategic goals might forgo important opportunities to anticipate and proactively shape the future of their business and harvest their potential competitive advantage. Moreover, it is likely that family owners will find some of their (financial or nonfinancial) goals unfulfilled when following this type of approach. Detaching strategic choices from where the family as the dominant coalition wants to go is doomed to provoke important criticism, notably from the family itself as it disregards the concerns, motivations, and aspirations of the family, one of the most central stakeholders in the firm.

\section{Prioritizing governance structures: Opportunities and challenges}

Anecdotal evidence shows that some family firms start the "fitting process" with neither goals nor resources but with the available governance structure of the firm. For instance, some family firms may take the prevailing control, incentive, and monitoring structures as a given and ask what can be achieved under these governance constraints. This approach might best ensure the "stability" of the organization, requires less managerial effort and does not infuse the organization with disruptive changes. Following the "strategy follows structure" paradigm (Burgelman, 1983), however, prevents family firms from adapting to changing environments and harvesting novel opportunities. Indeed, a focus on "how the firm has worked so far" will lead to path dependency (Sydow, Schreyögg, \& Koch, 2009) and, ultimately, organizational inertia.

A further challenge regarding setting the governance structures in family firms is defining the right level of governance within the firm: Too much governance does not only entail bureaucracy and ultimately hinders entrepreneurship but it also induces double agency costs (Carney, Gedajlovic, \& Strike, 2014; Child \& Rodrigues, 2003). Such costs occur when agents oversee other agents, thereby starting to act as principals and enjoying substantial leeway to align with subordinates and pursue their own interests (see also Zellweger \& Kammerlander, 2015). A lack of governance, however, entails a lack of accountability and efficiency and could further lead to abundant slack, which makes the company inert (LeonardBarton, 1992).

In addition to the formal governance structures, informal aspects of governance also need to be taken into account. In particular in family firms, not all decision-making processes will be formalized and written down, and social interaction of family as well as nonfamily members might replace contracts in organizational processes (Mustakallio, Autio, \& Zahra, 2002). Such informal governance elements also cover group dynamics in decision making, latent conflicts among decision-makers (Eddleston \&
Kellermanns, 2007), and communication within the organization. While often very efficient, such informal governance mechanisms also come with important challenges because they are often implicit and tacit and thus difficult to assess, especially for "outsiders" such as newly hired employees and managers. Moreover, such informal decision-making practices might be particularly hard to change. In the context of family firm governance, researchers have repeatedly pointed to relational governance, defined as any form of social control which likely affects the behavior of organizational members (Mustakallio et al., 2002; Suess, 2014). Relational governance thereby complements the contractual governance, that is control exerted through boards and other formalized mechanisms, and refers to, for instance, the communication of family members within the firm (Berent-Braun \& Uhlaner, 2012). An additional challenge for family firms is that the functioning of such relational governance mechanisms might crucially depend on the specific circumstances of the family firm, such as family structures or institutional context (Melin \& Nordqvist, 2007).

An additional characteristic element of governance in many family firms that deserves more scholarly attention is the existence of ceremonial governance elements. With ceremonial governance, we refer to governance elements such as advisory boards or decision-making committees that exist on paper but lack de facto power. For instance, based on in-depth case studies, Kammerlander and Ganter (2015: 368) describe a large, German family firm, in which the sole task of the board is to support the (family) CEO's decision-making preferences, which are shaped in private discussions prior to the actual board meetings. Ceremonial governance must not be seen as a path-dependent relic of bygone times but serves an important role by providing legitimacy within the firm but also to firm-external stakeholders. However, despite this raison d'être, scholars and practitioners that aim to assess a family firm's current governance mechanisms need to carefully distinguish between actual and ceremonial governance elements.

\section{Research opportunities at the nexus of goals, resources, and governance-Achieving an integrated perspective}

While much research effort has already been dedicated to understanding how family affects resources, goals, or governance structures in family firms, less research has been dedicated to the integration of these pieces and, in particular, to the fitting process among the three elements of our strategic framework. The dilemma about where to start the fitting process in light of the interdependent pieces of the whole mirrors a chicken-egg problem in strategizing: Do the "ends define the means" or the "means define the ends?" In our framework, the ends reflect the strategic goals, while the means represent the resources and governance structures. As shown above, there are good reasons for family firms to prioritize one of these aspects in their strategizing. At the same time, we have seen how limiting such a selective and sequential process can be, in particular for established companies that must cope with a more or less dynamic environment (Hill \& Rothaermel, 2003), such as most family firms.

These reflections lead us to conclude that a unilateral prioritization of means or ends will be shortsighted. Rather, under such a framework of strategic fit, strategizing aimed at creating value must consider both means and ends in parallel. This job of integrated strategizing is challenging because the parts (goals, resources, governance) are mutually contingent. For the case of a lone owner-manager, integrated strategizing and hence parallel consideration, alignment, and concertation of the three elements should be relatively easy because the communication and bargaining to determine the relative roles and the importance of goals, resources, and governance are all the responsibility of the 
same person. However, with an increasing number of involved people and business activities, that is, with the increasing separation of labor that is a prerequisite for value creation, the challenges will grow. In moving toward a better understanding of integrated strategic decision-making for value creation, we propose that unpacking the nexus of the three elements of value creation will open up several fruitful areas of further research.

The nexus of goals and resources: Reflections and opportunities for research

Much promise lies in the investigation of how goals and resources can be coordinated within family firms (arrow 4 in Fig. 1). How do family firms solve the means-ends dilemma about whether to prioritize goals versus resources? How do they avoid the dangers related to a unilateral focus on one of these two elements? One way to solve this dilemma could be an iterative adaptation process that synchronizes goals and resources. Such an iterative process requires the family to identify and define both goals and resources as a first step. Once this first step has been completed, goals and resources need to be matched in an iterative process. For instance, the family principals define a tentative goal and then review the appropriateness of this goal in light of the available resources. In the presence of resource constraints, the goals are adapted. The goal is to formulate a credible means-ends relationship between resources and goals through an iterative process.

Alternatively, and instead of defining specific goals, families may set relatively broad strategic guidelines in the form of acceptable, respectively, inacceptable strategic principles. These strategic guidelines should allow management to elaborate more specific goals in light of available resources. For instance, instead of formulating an overly challenging performance goal, the family may formulate a minimum threshold performance level that should secure the family's most central goals, such as upholding family control of the firm over time. Similarly, given the strong desire to keep control in family hands, the family owners may set a strategic guideline for the firm in the form of a minimum financial rating that translates into maximum leverage. For instance, the family owners of Henkel, a publicly listed German family firm, set a strategic guideline for management in the form of requiring a minimum of an A rating according to international rating agencies. This guideline translates into a boundary condition for the nonfamily management when taking on external capital, in particular debt, to finance the growth of the firm, such as via an acquisition. To further illustrate the usefulness of strategic guidelines, a concern for reputation could, for instance, translate into a definition of what the firm is not allowed to do in the form of a strategic "no go," such as engaging in so-called "sin industries" (Cai, Jo, \& Pan, 2012; Jo \& Na, 2012). Such guidelines replace the formulation of static goals, which could become obsolete and hamper strategic discretion under uncertainty.

In opening the black box of aligning goals and resources, process-oriented scholarly case studies could investigate this "fitting process" and the related mechanisms and potential pitfalls in more detail. Practitioners should aim to answer the following questions: What are the main goals of the family owners? What resources are available? Do the available resources support or hinder the family owners' goals? How can we adapt the resource base through leveraging, acquiring, and shedding resources to attain the goals?

The nexus of resources and governance: Reflections and opportunities for research

The question of how governance structures in family firms can support the efficient deployment of resources requires more scholarly attention as well (arrow 5 in Fig. 1). Because both governance structures and resources are typically heavily infused by the family, findings from other research streams focusing on non-family firms can only be applied to the family firm context in part and with caution. Sirmon, Hitt, and Ireland (2007) have recently started a scholarly debate about resource orchestration. This concept captures the notion that resources not only need to be available but also need to be deployed efficiently to create value. Sirmon et al. (2007) distinguish between structuring (acquire, accumulate, divest), bundling (stabilizing, enriching, pioneering), and leveraging (mobilizing, coordination, and deploying) resources. These authors remind us that if not orchestrated adequately, the family firm is likely to end up with a suboptimal resource base.

In this resource orchestration, governance structures should play a prominent role. This role starts with developing incentives to nudge management towards an efficient use of resources (Leonard-Barton, 1992). Alternatively, and as alluded to in the introduction of our paper, the family firm's monitoring systems and incentive schemes will determine the managers' leeway and motivation for pursuing activities in their own instead of in the owners' interest (Chrisman et al., 2004). In addition, governance structures determine the efficiency of information processing within the firm, which enables efficient resource orchestration.

In exploring the nexus of resources and governance, important conceptual groundwork has been completed (e.g., Sirmon et al., 2007; Sirmon, Hitt, Ireland, \& Gilbert, 2011). Beyond further conceptual refinements, this nexus may benefit most from some empirical testing of the propositions proposed in the related writings. For instance, we may find that some forms of governance, such as professionalized nonfamily management, may be positive in some aspects of resource orchestration, such as resource acquisition. At the same time, the very same governance constellation may negatively impact the coordination and deployment of resources. In this regard, empirical tests of the nuanced linkages between various forms of family firm governance and resource orchestration appear to hold much promise. We find certain governance constellations to be double-edged swords.

Most importantly, while resources must be adapted dynamically to be most effective, governance structures must be adapted as well. In particular, governance structures will need to change over the life cycle of the family firm. Founder-led firms, in particular in their early stages when they are still small, are often characterized by a relatively flat hierarchy and a general absence of reporting and monitoring structures. While such lean structures are most appropriate for small firms in which ownership and management fully converges, they need to be adapted as the firm grows. In particular, external investors expect professional mechanisms and structures with standardized reporting and monitoring processes. Also the increasing involvement of (non-family) managers renders more sophisticated governance structures necessary to avoid agency conflicts (Eisenhardt, 1989). However, several important challenges arise with the installation of these governance structures over time. First, family firms need to determine when to install governance structures. Second, they need to excel in implementation: What governance structures are implemented and how they are implemented. If complex governance structures are implemented too early, growth might be inhibited, as the firm becomes overly bureaucratic and slow. However, if there is a lack of appropriate governance structures, resources might be used inefficiently or might be deployed according to the interests of the (non-family) managers instead of the family owners. Moreover, if a set of new governance mechanisms such as reporting and monitoring activities is implemented too abruptly and without proper communication, the (non-family) employees might feel alienated. These employees, with their knowledge and commitment, have often substantially 
contributed to the previous growth and flourishing of the family firm, and they might therefore find it hard to accept that the new "stage" of the family firm requires more advanced reporting and monitoring systems, which often constrain individual employees or managers in terms of decision-making power and work-related leeway. Timely, transparent, and intensive communication and the active involvement of key employees is thus crucial if family firms want to adapt their governance structures without losing talented, experienced, and committed employees.

However, new governance is not only required as the family firm grows but might also be triggered through generational successions (Bammens, Voordeckers, \& Van Gils, 2008). While firm founders are often affine to technologies and might be experts on technical details, later generation family members at the top of the family firm often enjoy a business administration-related education, which gives them a leadership style based on financial rather than technical indicators. Successful governance structures in a model of fit need to mirror these preferences. In sum, family firms thus need to develop dynamic capabilities (Eisenhardt \& Martin, 2000) that encompass both the efficacious use of resources and adaptable governance structures.

Practitioners exploring the nexus of resources and governance could ask the following questions. What governance structures are in place in the family firm and why do they exist? Are things this way for historical reasons or because of "fit"? Have structures been adapted over the years? Are there constructive discussions about whether and how the extant governance structures support the efficacious deployment of resources?

The nexus of goals and governance: Reflections and opportunities for research

It is also important to coordinate family-based goals and governance structures (arrow 6 in Fig. 1). Literature on corporate governance (e.g., Shleifer \& Vishny, 1997) provides interesting insights into best governance practices, yet its application to the family firm context suffers amongst others because family firms might pursue different goals than non-family firms. Companies that look beyond short-term financial goals to also pursue longerterm financial and even non-financial goals, such as continuing family influence over time, might need different and more complex pay schemes, reporting systems, and incentive structures compared to non-family firms. More research is also required that distinguishes between the different and potentially diverging goals of family members, family owners, and firm(s). While within the family, harmony and justice might be considered the highest priority (Lambrecht \& Lievens, 2008), the firm-related priorities might be growth and long-term sustainability.

To account for those diverging goals, future research should differentiate between different types of governance in family firms (see also Table 2): Corporate governance studies on family firms investigate, for instance, organizational setup, reporting and monitoring structures, and pay schemes (e.g., Bartholomeusz \& Tanewski, 2006; McConaughy, 2000; Michiels, Voordeckers, Lybaert, \& Steijvers, 2013). With important insights also into contracting in family firms (Gómez-Mejía, Núñez-Nickel, \& Gutierrez, 2001) and family firm group structures (Almeida \& Wolfenzon, 2006; Carney, Gedajlovic, Heugens, Van Essen, \& Van Oosterhout, 2011; Luo \& Chung, 2005; Morck \& Yeung, 2003), this stream of literature can be considered to be relatively mature.

Less scholarly attention has been dedicated to date to the issue of ownership governance. Here, the assumption that a single family owner, or a homogenous group of family owners, respectively, owns and governs the firm is replaced by $m$ owners with potentially diverging interests, investment preferences, and overall goals. In particular, when those $m$ owners oversee $n$ assets, the complexity substantially increases compared to the "1:1" constellation (one block of family owners, one main asset, i.e., the "family firm") that is still at the center of most family business research. Ownership governance, which can be realized, for instance, through shareholder agreements, aims to regulate how the family owners interact with the firm(s). Shareholder agreements, for instance, regulate the execution of voting rights, the transfer of shares within and outside of the family pool, and the dividend policy of the firm (see Chemla, Habib, \& Ljungqvist, 2007 for details).

Family governance takes one additional step and defines family values and regulates current and future involvement of family in management and ownership. Regarding the managerial involvement of family members, family governance may provide answers to the following potentially contentious questions: Are family members allowed to work in the firm? What qualifications will be required? For what positions? What is the path that leads in to the family firm? How will we remunerate family members? What do the hiring and firing processes for family members look like? Regarding the ownership involvement of family members, family governance should answer the following questions: Who of the family can become owner (e.g., age, also in-laws)? How does one become an owner? How are shares passed on? What is the family's current and future ownership stake in the firm? What is the family's stance towards, e.g., IPOs, a partial sale, sale, private equity? But family governance may also make statements about

Table 2

Corporate, ownership, family and wealth governance in family firms.

\begin{tabular}{|c|c|c|c|}
\hline Form of governance & Goal & Key mechanisms and tools & Key literature \\
\hline Corporate Governance & $\begin{array}{l}\text { Assure the efficient supervising and } \\
\text { management of the firm }\end{array}$ & $\begin{array}{l}\text { Monitoring, incentive structures } \\
\text { Reporting, variable pay, managerial } \\
\text { ownership }\end{array}$ & $\begin{array}{l}\text { Family firm governance: e.g., Schulze et al. } \\
\text { (2001) } \\
\text { Governance in family business groups: Luo and } \\
\text { Chung (2005), Morck and Yeung (2003) }\end{array}$ \\
\hline Ownership governance & $\begin{array}{l}\text { Assure efficient cooperation among family } \\
\text { owners with potentially diverging } \\
\text { interests. Coordinate linkages between } \\
\text { family and nonfamily owners. }\end{array}$ & $\begin{array}{l}\text { Shareholder agreements, family } \\
\text { councils }\end{array}$ & $\begin{array}{l}\text { Law and finance: Chemla et al. (2007), } \\
\text { Easterbrook and Fischel (1986) }\end{array}$ \\
\hline Family governance & $\begin{array}{l}\text { Assure the efficient involvement of the } \\
\text { family in the firm, identify and establish a } \\
\text { committed family shareholder group }\end{array}$ & $\begin{array}{l}\text { Family charter, family meetings, family } \\
\text { constitution, family code of conducts }\end{array}$ & $\begin{array}{l}\text { Family governance advisory: Angus (2005), } \\
\text { Berent-Braun and Uhlaner (2012), Hauser } \\
\text { (2002), Koeberle-Schmid, Kenyon-Rouvinez, } \\
\text { and Poza (2014), Martin (2001), Ward and } \\
\text { Aronoff (2010) }\end{array}$ \\
\hline Wealth governance & $\begin{array}{l}\text { Assure the efficient administration of } \\
\text { family wealth, counter the fragmentation of } \\
\text { family wealth }\end{array}$ & $\begin{array}{l}\text { Family offices, trusts, gifting, } \\
\text { inheritance, buy-sell agreements }\end{array}$ & $\begin{array}{l}\text { Wealth governance: } \\
\text { Zellweger and Kammerlander (2015) } \\
\text { Estate planning: Ellul et al. (2010), Tsoutsoura } \\
\text { (2014) }\end{array}$ \\
\hline
\end{tabular}


the social activities of the family. Tools such as family charters can help achieve these goals. The underlying goal is to assure the proficient and committed engagement of the family vis-a-vis the firm. Family governance is unique to family firms but has received relatively little scholarly attention (Suess, 2014). This is surprising in light of its prominent role in the advisory work with family firms and related writings.

Lastly, wealth governance not only covers the firms owned by one family but also considers other assets such as liquid wealth or real estate that might serve as a source of capital for family firms (Zellweger \& Kammerlander, 2015). This form of governance serves as a force against the fragmentation of family wealth across generations and regulates access to and the distribution of wealth. Given the need to counter the fragmentation of wealth for the longterm success of family-controlled business activity (Bennedsen, Fan, Jian, \& Yeh, 2015; Franks, Mayer, Volpin, \& Wagner, 2012), more research is needed on this aspect of governance. Here, the broad literature on estate planning deserves further consideration by family business scholars (Bertrand et al., 2008; Ellul, Pagano, \& Panunzi, 2010; Tsoutsoura, 2014).

Corporate, ownership, family, and wealth governance have received attention from the different streams of research throughout recent years (see Table 2)-in the future, it would be desirable to work on a more integrated perspective that includes the various forms of governance. To do so, applying a system theoretical perspective (Von Schlippe \& Frank, 2013) to the various forms of governance might be useful. Practitioners confronted with governance issues might consider the following questions: Do governance principles exist for all of the levels discussed abovefirm, owners, family, and wealth? How are they coordinated and aligned? Are they adapted to the existing goals? How effective are they at mitigating potential conflicts?

\section{Nexus between institutional context, goals, resources, and governance}

Finally, the family firm does not exist independently but is always embedded in an environmental context number 7 in Fig. 1). The environment shapes the family firm in various ways. First, recent family firm publications (e.g., Carney et al., 2014; Zellweger \& Kammerlander, 2015) indicate that the appropriability of governance structures might critically depend on the institutional context because of, for instance, differences in tax and legal systems. Specifically, formal institutions might shape the predominance of family firms in the respective country (Van Essen, Van Oosterhout, \& Heugens, 2013), in particular because legal systems might foster or impede the rights of blockholders. Family firms might thus particularly flourish in emerging economies with weak institutions, in which the relational ties of families can bear particular benefits (Carney, 2005). When minority shareholder rights are strongly protected in a specific country (La Porta, Lopezde-Silanes, Shleifer, \& Vishny, 2002), the influence of the family on the firm's strategy, in particular the use of resources and the installment of governance structures, might be substantially constrained.

But also, for instance, labor market institutions, which regulate the supply of qualified managerial labor (Meyer, Estrin, Bhaumik, \& Peng, 2009), are of critical importance for the "fit" of family firms within their environment. Such institutions affect the availability of important resources, such as well-educated engineers and managers, in a specific country and thus determine how well family firms can orchestrate their resources (Duran et al., 2015). As a consequence, the need of family firms to operate efficiently is dependent on institutions.

In addition, not only institutions but also extant stakeholders can shape the family firm's goals, resources, and structures. Family firms have been shown to be particularly inclined to strive to gain legitimacy (Miller et al., 2013). Hence, they are likely to strive to please external stakeholders such as financial analysts (if publically listed) or local officials in order to thereby gain legitimacy. As a consequence, those stakeholders might influence the family's goals with respect to Corporate Social Responsibility (Berrone et al., 2010) or might affect how specific governance structures are installed or how resources are deployed.

Summarized, it would be interesting to study value creation in family firms also in the light of different institutional contexts and by taking account of the role of various important stakeholders. From a practical point of view, it is important to ask the following questions: What makes the context of the family firm unique? Are, for instance, any family-influenced resources abundantly available? Are there governance mechanisms that allow for superior harvesting of the family firm's competitive advantages? What stakeholders are particularly important for the family firm? And how do these important stakeholders affect the family firm?

\section{Conclusion}

Value creation in family firms can be realized through a fit between goals, resources, and governance structures, all of which are typically influenced by the family. We encourage researchers to take an integrated perspective to determine the contingencies of when and how family influence can contribute to value creation. In this article, we propose a "model of fit" and argue that taking an integrated perspective will help both academics and practitioners to generate a more nuanced understanding of value creation (and destruction) in family firms. Moreover, as we outlined, this framework also allows the identification of new, promising areas for further research on family firms.

\section{References}

Ahrens, J.-P., Landmann, A., \& Woywode, M. (2015). Gender preferences in CEO successions in family firms: Family characteristics and human capital of the successor. Journal of Family Business Strategy, 6(2), 86-103.

Almeida, H. V., \& Wolfenzon, D. (2006). A theory of pyramidal ownership and family business groups. The Journal of Finance, 61(6), 2637-2680.

Anderson, R. C., \& Reeb, D. M. (2003). Founding-family ownership and firm performance: Evidence from the S\&P 500. The Journal of Finance, 58(3), 1301-1328.

Andriopoulos, C., \& Lewis, M. W. (2009). Exploitation-exploration tensions and organizational ambidexterity: Managing paradoxes of innovation. Organization Science, 20(4), 696-717.

Angus, P. M. (2005). The family governance pyramid: From principles to practice. The Journal of Wealth Management, 8(1), 7-13.

Bammens, Y., Voordeckers, W., \& Van Gils, A. (2008). Boards of directors in family firms: A generational perspective. Small Business Economics, 31(2), 163-180.

Barney, J. (1991). Firm resources and sustained competitive advantage. Journal of Management, 17(1), 99-120.

Bartholomeusz, S., \& Tanewski, G. A. (2006). The relationship between family firms and corporate governance. Journal of Small Business Management, 44(2), 245-267.

Bennedsen, M., Fan, J. P., Jian, M., \& Yeh, Y.-H. (2015). The family business map: Framework, selective survey, and evidence from Chinese family firm succession. Journal of Corporate Finance. http://dx.doi.org/10.1016/j.jcorpfin.2015.01.008 (in press).

Berent-Braun, M. M., \& Uhlaner, L. M. (2012). Family governance practices and teambuilding: Paradox of the enterprising family. Small Business Economics, 38(1), 103-119.

Berrone, P., Cruz, C., \& Gómez-Mejía, L. R. (2012). Socioemotional wealth in family firms: Theoretical dimensions, assessment approaches, and agenda for future research. Family Business Review, 25(3), 258-279.

Berrone, P., Cruz, C., Gómez-Mejía, L. R., \& Larraza-Kintana, M. (2010). Socioemotional wealth and corporate responses to institutional pressures: Do family-controlled firms pollute less? Administrative Science Quarterly, 55(1), 82-113.

Bertrand, M., Johnson, S., Samphantharak, K., \& Schoar, A. (2008). Mixing family with business: A study of Thai business groups and the families behind them. Journal of Financial Economics, 88(3), 466-498.

Block, J. H. (2011). How to pay nonfamily managers in large family firms: A principalAgent model. Family Business Review, 24(1), 9-27.

Boyd, B. (2010). Sustainable management in long-lived family businesses-A resourcebased analysis of Northern German builder's providers. International Journal of Entrepreneurship and Small Business, 11(3), 308-321.

Brinckmann, J., Grichnik, D., \& Kapsa, D. (2010). Should entrepreneurs plan or just storm the castle?. A meta-analysis on contextual factors impacting the business 
planning-performance relationship in small firms. Journal of Business Venturing 25(1), 24-40.

Burgelman, R. A. (1983). A model of the interaction of strategic behavior, corporate context, and the concept of strategy. Academy of Management Review, 8(1), 61-70.

Cabrera-Suarez, K., Saa-Perez, P., \& Garcia-Almeida, D. (2001). The succession process from a resource- and knowledge-based view of the family firm. Family Business Review, 14(1), 37-48.

Cai, Y., Jo, H., \& Pan, C. (2012). Doing well while doing bad?. CSR in controversial industry sectors. Journal of Business Ethics, 108(4), 467-480.

Cameron, K. S. (1986). Effectiveness as paradox: Consensus and conflict in conceptions of organizational effectiveness. Management Science, 32(5), 539-553.

Carney, M. (2005). Corporate governance and competitive advantage in family-controlled firms. Entrepreneurship Theory and Practice, 29(3), 249-265.

Carney, M., Gedajlovic, E., \& Strike, V. M. (2014). Dead money: Inheritance law and the longevity of family firms. Entrepreneurship Theory and Practice, 38(6), 1261-1283.

Carney, M., Gedajlovic, E. R., Heugens, P. P., Van Essen, M., \& Van Oosterhout, J. H. (2011). Business group affiliation, performance, context, and strategy: A metaanalysis. Academy of Management Journal, 54(3), 437-460.

Chemla, G., Habib, M. A., \& Ljungqvist, A. (2007). An analysis of shareholder agreements. Journal of the European Economic Association, 5(1), 93-121.

Child, J., \& Rodrigues, S. B. (2003). Corporate governance and new organizational forms: Issues of double and multiple agency. Journal of Management and Governance, 7(4), 337-360.

Chrisman, J. J., Chua, J. H., De Massis, A., Frattini, F., \& Wright, M. (2015). The ability and willingness paradox in family firm innovation. Journal of Product Innovation Management, 32(3), 310-318.

Chrisman, J. J., Chua, J. H., \& Litz, R. A. (2004). Comparing the agency costs of family and non-family firms: Conceptual issues and exploratory evidence. Entrepreneurship Theory and Practice, 28(4), 335-354.

Chrisman, J. J., Chua, J. H., Pearson, A. W., \& Barnett, T. (2012). Family involvement, family influence, and family-centered non-economic goals in small firms. Entrepreneurship Theory and Practice, 36(2), 267-293.

Cole, P. M. (1997). Women in family business. Family Business Review, 10(4), 353-371

Corbetta, G., \& Salvato, C. (2004). Self-serving or self-actualizing? Models of man and agency costs in different types of family firms: A commentary on "Comparing the agency costs of family and non-family firms: Conceputal issues and exploratory evidence". Entrepreneurship Theory and Practice, 28(4), 355-362.

Drazin, R., \& Van de Ven, A. H. (1985). Alternative forms of fit in contingency theory. Administrative Science Quarterly, 30(4), 514-539.

Duran, P., Kammerlander, N., van Essen, M., \& Zellweger, T. (2015). Innovation input and innovation output in family firms: A meta-analysis. In CFB-HSG (Ed.), Working paper. Switzerland: University of St. Gallen.

Easterbrook, F. H., \& Fischel, D. R. (1986). Close corporations and agency costs. Stanford Law Review, 38, 271-301.

Eddleston, K. A., \& Kellermanns, F. W. (2007). Destructive and productive family relationships: A stewardship theory perspective. Journal of Business Venturing, 22(4), 545-565

Eisenhardt, K. M. (1989). Agency theory: An assessment and review. Academy of Management Review, 14(1), 57-74.

Eisenhardt, K. M., \& Martin, J. A. (2000). Dynamic capabilities: What are they? Strategic Management Journal, 21(10/11), 1105-1121.

Ellul, A., Pagano, M., \& Panunzi, F. (2010). Inheritance law and investment in family firms. The American Economic Review, 100(5), 2414-2450.

Engel, P. J., Hack, A., \& Kellermanns, F. W. (2015). Setting the right mix-Analyzing outside directors' pay mix in public family firms. Journal of Family Business Strategy, 6(2), 130-140.

Franks, J., Mayer, C., Volpin, P., \& Wagner, H. F. (2012). The life cycle of family ownership: International evidence. Review of Financial Studies, 26(6), 1675-1712.

Gibson, C. B., \& Birkinshaw, J. (2004). The antecedents, consequences, and mediating role of organizational ambidexterity. Academy of Management Journal, 47(2), 209-226.

Gómez-Mejía, L. R., Larraza-Kintana, M., \& Makri, M. (2003). The determinants of executive compensation in family-controlled public corporations. Academy of Management Journal, 46(2), 226-237.

Gómez-Mejía, L. R., Núñez-Nickel, M., \& Gutierrez, I. (2001). The role of family ties in agency contracts. Academy of Management Journal, 44(1), 81-95.

Gómez-Mejía, L. R., Takács Haynes, K., Núnez-Nickel, M., Jacobson, K. J. L., \& MoyanoFuentes, J. (2007). Socioemotional wealth and business risks in family-controlled firms: Evidence from Spanish olive oil mills. Administrative Science Quarterly, 52(1), 106-137.

Habbershon, T. G., \& Williams, M. L. (1999). A resource-based framework for assessing the strategic advantages of family firms. Family Business Review, 12(1), 1-25.

Habbershon, T. G., Williams, M. L., \& MacMillan, I. C. (2003). A unified systems theory of family firm performance. Journal of Business Research, 18(4), 451-465.

Hauck, J., \& Prügl, R. (2015). Innovation activities during intra-family leadership succession in family firms: An empirical study from a socioemotional wealth perspective. Journal of Family Business Strategy, 6(2), 104-118.

Hauser, B. R. (2002). Family governance: Who, what, and how. The Journal of Wealth Management, 5(2), 10-16.

He, L. (2008). Do founders matter?. A study of executive compensation, governance structure and firm performance. Journal of Business Venturing, 23(3), 257-279.

Hill, C. W., \& Rothaermel, F. T. (2003). The performance of incumbent firms in the face of radical technological innovation. Academy of Management Review, 28(2), 257-274.

Hollander, B. S., \& Bukowitz, W. R. (1990). Women, family culture, and family business. Family Business Review, 3(2), 139-151.

Jarzabkowski, P. (2004). Strategy as practice: Recursiveness, adaptation, and practicesin-use. Organization Studies, 25(4), 529-560.
Jo, H., \& Na, H. (2012). Does CSR reduce firm risk?. Evidence from controversial industry sectors. Journal of Business Ethics, 110(4), 441-456.

Kammerlander, N., Burger, D., Fust, A., \& Fueglistaller, U. (2014). Exploration and exploitation in established small and medium-sized enterprises: The effect of CEOs' regulatory focus. Journal of Business Venturing. http://dx.doi.org/10.1016/ j.jbusvent.2014.09.004 (in press).

Kammerlander, N., \& Ganter, M. (2015). An attention-based view of family firm adaptation to discontinuous technological change: Exploring the role of family CEOs' noneconomic goals. Journal of Product Innovation Management, 32(3), 361-383.

Kellermanns, F. W., Eddleston, K. A., \& Zellweger, T. M. (2012). Extending the socioemotional wealth perspective: A look at the dark side. Entrepreneurship Theory and Practice, 36(6), 1175-1182.

Koeberle-Schmid, A., Kenyon-Rouvinez, D., \& Poza, E. J. (2014). Governance in family enterprises. New York, NY: Palgrave Macmillan.

König, A., Kammerlander, N., \& Enders, A. (2013). The family innovator's dilemma: How family influence affects the adoption of discontinuous technologies by incumbent firms. Academy of Management Review, 38(3), 418-441.

Konrad, K. A. (2009). Strategy and dynamics in contests. Oxford, UK: Oxford University Press.

Krappe, A., Goutas, L., \& von Schlippe, A. (2011). The "family business brand": An enquiry into the construction of the image of family businesses. Journal of Family Business Management, 1(1), 37-46.

La Porta, R., Lopez-de-Silanes, F., Shleifer, A., \& Vishny, R. (2002). Investor protection and corporate valuation. Journal of Finance, 57(3), 1147-1170.

Lambrecht, J., \& Lievens, J. (2008). Pruning the family tree: An unexplored path to family business continuity and family harmony. Family Business Review, 21(4), 295-313.

Lee, M. S., \& Rogoff, E. G. (1996). Research note: Comparison of small businesses with family participation versus small businesses without family participation: An investigation of differences in goals, attitudes, and family/business conflict. Family Business Review, 9(4), 423-437.

Leonard-Barton, D. (1992). Core capabilities and core rigidities: A paradox in managing new product development. Strategic Management Journal, 13(1), 111-125

Locke, E. A., \& Latham, G. P. (2002). Building a practically useful theory of goal setting and task motivation: A 35-year odyssey. American Psychologist, 57(9), 705.

Lopez-Delgado, P., \& Dieguez-Soto, J. (2015). Lone founders types of private family businesses and firm performance. Journal of Family Business Strategy, 6(2), 73-85.

Luo, X., \& Chung, C.-N. (2005). Keeping it all in the family: The role of particularistic relationships in business group performance during institutional transition. Administrative Science Quarterly, 50, 404-439.

Luo, X. R., \& Chung, C.-N. (2013). Filling or abusing the institutional void?. Ownership and management control of public family businesses in an emerging market. Organization Science, 24(2), 591-613.

Lüscher, L. S., \& Lewis, M. W. (2008). Organizational change and managerial sensemaking: Working through paradox. Academy of Management Journal, 51(2), 221-240.

Martin, H. F. (2001). Is family governance an oxymoron? Family Business Review, 14(2), 91-96.

McConaughy, D. L. (2000). Family CEOs vs nonfamily CEOs in the family-controlled firm: An examination of the level and sensitivity of pay to performance. Family Business Review, 13(2), 121-131.

Melin, L., \& Nordqvist, M. (2007). The reflexive dynamics of institutionalization: The case of the family business. Strategic Organization, 5(3), 321-333.

Meyer, K. E., Estrin, S., Bhaumik, S., \& Peng, M. W. (2009). Institutions, resources, and entry strategies in emerging economies. Strategic Management Journal, 30(1), $61-80$.

Michiels, A., Voordeckers, W., Lybaert, N., \& Steijvers, T. (2013). CEO compensation in private family firms pay-for-performance and the moderating role of ownership and management. Family Business Review, 26(2), 140-160.

Miller, D., \& Le Breton-Miller, I. (2005). Managing for the long run. Boston, MA: Harvard Business School Press.

Miller, D., Le Breton-Miller, I., \& Lester, R. H. (2013). Family firm governance, strategic conformity, and performance: Institutional vs. strategic perspectives. Organization Science, 24(1), 189-209.

Miller, D., Le Breton-Miller, I., Lester, R. H., \& Cannella, A. A., Jr. (2007). Are family firms really superior performers? Journal of Corporate Finance, 13(5), 829-858.

Morck, R., \& Yeung, B. (2003). Agency problems in large family business groups. Entrepreneurship Theory and Practice, 27(4), 367-382.

Mustakallio, M., Autio, E., \& Zahra, S. A. (2002). Relational and contractual governance in family firms: Effects on strategic decision making. Family Business Review, 15(3), 205-222.

O’Boyle, E. H., Jr., Pollack, J. M., \& Rutherford, M. W. (2012). Exploring the relation between family involvement and firms' financial performance: A meta-analysis of main and moderator effects. Journal of Business Venturing, 27(1), 1-18.

Pearson, A. W., Carr, J. C., \& Shaw, J. C. (2008). Toward a theory of familiness: A social capital perspective. Entrepreneurship Theory and Practice, 32(6), 949-969.

Peng, M. W., \& Jiang, Y. (2010). Institutions behind family ownership and control in large firms. Journal of Management Studies, 47(2), 253-273.

Sarasvathy, S. D. (2001). Causation and effectuation: Toward a theoretical shift from economic inevitability to entrepreneurial contingency. Academy of Management Review, 26(2), 243-263.

Schulze, W. S., Lubatkin, M. H., \& Dino, R. N. (2003). Exploring the agency consequences of ownership dispersion among the directors of private family firms. Academy of Management Journal, 46(2), 179-194.

Schulze, W. S., Lubatkin, M. H., Dino, R. N., \& Buchholtz, A. K. (2001). Agency relationships in family firms: Theory and evidence. Organization Science, 12(2), 99-116.

Sharma, P. (2008). Commentary: Familiness: Capital stocks and flows between family and business. Entrepreneurship Theory and Practice, 32(6), 971-977. 
Shleifer, A., \& Vishny, R. W. (1997). A survey of corporate governance. The Journal of Finance, 52(2), 737-783.

Sieger, P., Zellweger, T., Nason, R. S., \& Clinton, E. (2011). Portfolio entrepreneurship in family firms: A resource-based perspective. Strategic Entrepreneurship Journal, 5(4), 327-351.

Sirmon, D. G., \& Hitt, M. A. (2003). Managing resources: Linking unique resources, management, and wealth creation in family firms. Entrepreneurship Theory and Practice, 27(4), 339-358.

Sirmon, D. G., Hitt, M. A., \& Ireland, R. D. (2007). Managing firm resources in dynamic environments to create value: Looking inside the black box. Academy of Management Review, 32(1), 273-292.

Sirmon, D. G., Hitt, M. A., Ireland, R. D., \& Gilbert, B. A. (2011). Resource orchestration to create competitive advantage breadth, depth, and life cycle effects. Journal of Management, 37(5), 1390-1412.

Sitthipongpanich, T., \& Polsiri, P. (2015). Do CEO and board characteristics matter?.-A study of Thai family firms. Journal of Family Business Strategy:, 6(2), 119-129.

Smith, W. K., \& Lewis, M. W. (2011). Toward a theory of paradox: A dynamic equilibrium model of organizing. Academy of Management Review, 36(2), 381-403.

Suess, J. (2014). Family governance-Literature review and the development of a conceptual model. Journal of Family Business Strategy, 5(2), 138-155.

Sydow, J., Schreyögg, G., \& Koch, J. (2009). Organizational path dependence: Opening the black box. Academy of Management Review, 34(4), 689-709.

Tagiuri, R., \& Davis, J. (1996). Bivalent attributes of the family firm. Family Business Review, 9(2), 199-208.

Tsoutsoura, M. (2014). The effect of succession taxes on family firm investment: Evidence from a natural experiment. The Journal of Finance, 70(2), 649-688.
Van Essen, M., Van Oosterhout, J., \& Heugens, P. P. M. A. R. (2013). Competition and cooperation in corporate governance: The effects of labor institutions on blockholder effectiveness in 23 European countries. Organization Science, 24(2), 530551.

Von Schlippe, A., \& Frank, H. (2013). The theory of social systems as a framework for understanding family businesses. Family Relations, 62(3), 384-398.

Wagner, D., Block, J. H., Miller, D., Schwens, C., \& Xi, G. (2015). A meta-analysis of the financial performance of family firms: Another attempt. Journal of Family Business Strategy, 6(1), 3-13.

Ward, J. L., \& Aronoff, C. E. (2010). Family business governance: Maximizing family and business potential. New York, NY: Palgrave Macmillan.

Wennberg, K., Wiklund, J., Hellerstedt, K., \& Nordqvist, M. (2011). Implications of intrafamily and external ownership transfer of family firms: Short-term and long-term performance differences. Strategic Entrepreneurship Journal, 5(4), 352-372.

Whittington, R. (1996). Strategy as practice. Long Range Planning, 29(5), 731-735.

Wiseman, R. M., \& Gómez-Mejía, L. R. (1998). A behavioral agency model of managerial risk taking. Academy of Management Review, 23(1), 133-153.

Zellweger, T. (2013). Toward a paradox perspective of family firms: The moderating role of collective mindfulness of controlling families. In L. Melin, M. Nordqvist, \& P. Sharma (Eds.), The SAGE handbook of family business (pp. 648-655). Thousand Oaks, CA: SAGE Publications.

Zellweger, T., \& Kammerlander, N. (2015). Family, wealth, and governance: An agency account. Entrepreneurship Theory and Practice (in press).

Zellweger, T. M., Kellermanns, F. W., Chrisman, J. J., \& Chua, J. H. (2012). Family control and family firm valuations by family CEOs: The importance of intentions for transgenerational control. Organization Science, 23(2), 851-868. 